\title{
A Living Archive: Women's AbSences ANd The Painterly (RE)INSCRIPTIONS OF THE GENDERED NATION
}

\author{
MIRANDA IMPERIAL \\ London School of Economics and Political Science \\ miranda.imperial@gmail.com
}

Received: $15-10-2018$

Accepted: 04-02-2019

\begin{abstract}
In recent years, within the concept of the archive there has been an ever-increasing notion that points to a repository for classification, cultural production, a locus for keeping the records of history, a paying tribute to memory, whilst, simultaneously, registering as much as what is kept as what is lost. My paper is a work-in-progress, and, as such, an exploration of what I call a "living archive," an archive in the making, where, by recourse to a culturally rich repository of images of Indian women as represented by Indian women artists along the twentieth century, I will address women's invisibility from official history. Generationally arranged, my choice of painters includes Sunayani Devi (1875-1962), Amrita Sher-Gil (1913-1941) and Nalini Malani (1946-). Women artists in all these cases were privileged and educated, and developed a career in the Fine Arts. They all show a great interest and concern in the role of women within society, and they have portrayed and captured women and women's relations and work with attention. In most cases, they exhibit a feminist or proto-feminist awareness. From the visual format of the canvas both in historical perspective and at present, I will attempt to discuss how their work and their valuable repository of images is certainly evidence of significant historical and cultural change.
\end{abstract}

KEYWORDS: archive, representation, painting, Indian women painters, Sunayani Devi, Amrita Sher-Gil, Nalini Malani, Indian nation

RESUMEN Un archivo viviente: La ausencia de las mujeres y la reinscripción del género en la nación a través de la pintura

En los últimos años ha ganado preponderancia la idea del archivo como depósito para la clasificación y la producción cultural, así como espacio para los registros históricos, rindiendo tributo a la memoria colectiva y registrando tanto lo conservado como lo que se ha perdido. Este artículo es work-in-progress centrado en explorar lo que llamo un «archivo viviente» en construcción, mediante el cual, aprovechando la riqueza del repositorio en representaciones de mujeres de la India pintadas por artistas indias del siglo XX, abordaré la invisibilidad de la mujer en la historia oficial. Ordenadas cronológicamente, incluyo a pintoras como Sunayani Devi (1875-1962), Amrita Sher-Gil (1913-1941) y Nalini Malani (1946). Todas estas pintoras, privilegiadas y cultas, iniciaron una carrera artística en la que demostraron gran interés y preocupación por el papel de la mujer en la sociedad, captando con atención y a menudo desde una conciencia feminista o protofeminista, tanto la figura de la mujer como sus relaciones y su trabajo. Tomando el lienzo como soporte, y con una perspectiva tanto histórica como actual, abordaré cómo su obra y su valioso legado de imágenes evidencian un significativo cambio a nivel histórico y cultural.

Palabras Clave: archivo, representación, pintura, pintoras de la India, Sunayani Devi, Amrita Sher-Gil, Nalini Malani, nación India 
In her seminal essay "Can the Subaltern Speak?” (1983), Gayatri Chakravorty Spivak raises critical questions about the way in which imperial, nationalist, and even anti-colonial and alternative theories have played a complicit role in maintaining the silence of the subaltern. By subaltern, Spivak means those (non-essentialized) subjects who have been excluded from the right to speak, those who occupy the "silences" (1983: 286) - especially women - in the colonial and postcolonial context. Spivak employs Foucault's notion of the "episteme" (1983: 298), nevertheless she critiques the French philosopher's way of representing those outside the discourses of power, who is forgetful of their subjectivities and idiosyncrasies and, in many ways, essentializes their exclusion.

In Spivak's view, 'the substantive concern for the politics of the oppressed which often accounts for Foucault's appeal can hide a privileging of the intellectual" (1983: 292). As a result, theories and academia "speak to (rather than listen to or speak for) the historically muted subject" (1983: 295).

In what follows, I will consider the "Subaltern" as woman, although today the inclusion of women within subalternity is a contested idea, considering that there are very many "categories" of subalterns. Precisely due to their absence, I view Indian women as occupying an important position in the archive, an "empty signifier" which can be filled by an exploited domestic worker, a tribal farm labourer, or even a bourgeois woman.

The proposal of this paper is to apply a process of reading and, furthermore, a challenging of the construction of India as a modern nation with crucial and significant absences, such as those of women as subjects of representation in the Fine Arts. No doubt, there is a whole domain of experience which remains "undocumented". Whereas the archive is a site where history is preserved, in our case, the archival subject, woman (or better said, women), is elusive, invisible and, thus, cannot be documented. Our archive will necessarily be a text of silence (historical silencing of women's experiences) that is interrupted and fractured by an "official" voice which we mark as a male voice. Women have traditionally been excluded from the archive. Women's experiences, thus, remain lost to history, whether colonial, post-colonial histories, and even at present within free democratic nations. 


\section{Imagined Archives: The Nation}

In his classical account of the modern nation, Imagined Communities (1983), Benedict Anderson asserted that the lineage of nationalism could be traced down to the interplay of three major institutions, namely: the census, the map and the museum. Anderson's thoughts on the museum highlight that the imaginings of a common ancestry are profoundly political. He suggests that the reasons for the rise of the museum are that such archaeological efforts to construct monuments are linked to the superiority of the state. Through museums, the power of the state as the guardian of tradition becomes patent. In Anderson's view, these institutions show the drive to classify different nationalities in physical terms and "illuminate[d] the late colonial state's style of thinking about its domain" (1983: 184). The museum houses collections, and some of these collections have their origin in an archive.

In parallel, in Nations and Nationalism since 1780 (2012), Eric Hobsbawm critiques the employment of "cultural capital" by the elite in power — whether colonial or native - in order to legitimize the consistency between the state and a national identity. In this respect, what is missing is, in his view, "[ $[\mathrm{t}]$ hat view from below, i.e. the nation as seen not by governments and the spokesmen and activist of nationalist (or non-nationalist) movements, but the ordinary persons who are the objects of their action and propaganda, is exceedingly difficult to discover. [ ...] official ideologies of states and movements are not guides of what it is in the minds of even the most loyal citizens or supporters" (2012: 11). In the process of consolidating colonial occupation in former colonized nations, archives excluded the voices of the very persons being represented -in the Subaltern Studies Group, these would be the "subaltern" - which resulted in the fact that post-independence states were not exempt from the same colonial exclusions in the production of a national identity.

In this frame, we may raise the question of: who has the right to "speak" on and about the archive, or from within the archive, and what is the place of the subaltern within this configuration? Finally, and by extension, what is the role accorded to women within colonial India and in the context of the post-independence nation?

Regarding the archive, collections, classification and "memorialization", these ideas are all very central elements within contemporary culture. Historian Pierre Nora 
has argued that we inhabit a time obsessed with the idea of the archive, and in an archival culture, "no society has even produced archives as deliberately as our own, not only by volume, not only by technical means of reproduction and preservation, but also by its superstitious esteem, by its veneration of the trace" (1989: 13).

In the twenty-first century, many of us feel the responsibility to "respond" to the demands of History by confronting our national histories - both in their documents and in the remaining cultural artefacts - and History's losses, or to (re)construct the narrative of who we are both as a people and as citizens of a country.

In nationalist debates about the role that women might play in the development of the nation and national identity, women's bodies — and not any other aspect of their lives_- was an issue of primary concern (Mill, 1869; Sarkar, 2010). But women's voices, their work and cultural production, did articulate resistance to the ways in which they were being imagined by the state. The periods of nationalism in pre-partition India, and later on in an independent India and Pakistan, coincide with women's resistance movements.

In the domain of the Fine Arts, while working with masculine constructs of femininity, women artists adhered to traditional genre painting in these historical moments to discuss all issues that could not, in their socio-historical contexts, be represented, in the open.

In this paper, my choice of artists challenges the idea that only men are active participants in the public sphere (Fraser, 1990) by showing that precisely when their identities are most vulnerable — and their bodies and sexualities become a matter of public debate - women artists representing other women, solidarity and community (see Mohanty, 2003) come out into the public sphere. This paper suggests that sexuality, as a category of analysis, is fundamental in unraveling the workings of nationalism in South Asia. Furthermore, I shall point to the disappearance of women's cultural productions and argue that women's art has become an important conceptual metaphor of resistance.

\section{A Living Archive}


In my paper, I aim to construct that fragment of the archive where the experience of Indian women is absent or immaterial. Although we lack the materiality of "archival memory", it is through the representations of Indian women artists that I will be looking at, and, in this respect we shall gain access to other kinds of memory, such as sense or affective memory. Ann Cvetkovich's concept of "archive of feelings" 1 proves how affective experience can be fruitfully used as the basis of new cultures, and defined the archive as "an exploration of cultural texts as repositories of feelings and emotions, which are encoded not only in the content of the texts themselves but in the practices that surround their production and reception" (2003: 7). Cvetkovich's idea of “culture/s" draws from Raymond Williams's "culture as a way of life" (1958). In her view, publics are formed in and through cultural archives while remaining attentive to forms of affective life that do not materialize in institutions or organizations, in an attempt at "support[ing] forms of affective, erotic and personal living that are public in the sense of accessible, available to memory, and sustained through collective activity" (2003: 9).

I will also be working with the notion of the "living archive." A living archive is an open archive, an archive-in-the-making, where linearity in time and space is undermined, and the interest of the archivist or the engaged scholar lies in identifying that which was never collected or deemed important. The living archive should be a collaborative project in which the work and experiences of Indian women, as women, artists, creators, come together to document the hidden history of women in India in every possible aspect of their existence. For Hogan (2012), the living archive's aim is

not to bury the past in boxes or databases for posterity, but to 'unearth fresh forms of thinking from what has gone before.' The 'living' component of this archival framework is thus twofold: on the one hand it is about access as it encourages researchers to make connections between materials and to map out their own archival journeys in hopes of 'revealing new ways of looking at the future by examining the past' (2012: 24).

The living archive is far from being fixed, as current ongoing research proves. The idea of the archive, as a repository of collective memory, has also been linked to

\footnotetext{
${ }^{1}$ As is amply known, Cvetkovich focuses on queer cultures, and specifically on lesbian public cultures. She explores the connection between sexual trauma, identities and community, across activism, performance and literature.
} 
the knowledge and practices of the colony, namely those groups coming from dominated and subaltern constituencies. To delineate the imagined boundaries of our archive, I will hold that the archive I propose is a work-in-progress; an exploration of what I call a "living archive," an archive in the making. Drawing from a culturally rich repository of images of Indian women as represented by Indian women artists throughout the twentieth century, I will address womens' invisibility from official history. Generationally arranged, my choice of painters includes Sunayani Devi (18751962), Amrita Sher-Gil (1913-1941) and Nalini Malani (1946-). The aforementioned belong to three crucial generations of Indian women artists, from primitivism and modernism, to the 1970s and up to the present moment.

My approach to the paintings in this paper aims at complementing how scholars of post-coloniality have theorized and understood women's voices vis-à-vis discourses on nationalism. Post-colonial scholarship on nationalism has tended to focus more on writing, and on the genre of the novel and non-fiction rather than on the Fine Arts. I hold that a study of women's visual art during these very moments of nationalism would enrich the topography of Fine Arts sociology. In this way, we can begin to understand the space that art engenders for feminist social critique at historical moments, considering that the focus seems to be fixed on other forms of political expression.

As mentioned above, this paper also traces both the discourse of the national and that of the modern through an analysis of two exemplary careers (Sunayani Devi and Amrita Sher-Gil) and one contemporary painter (Nalini Malani). Through those careers we can trace the evolution of women's painting in two crucial generations of art practice in India; from the colonial to the postcolonial period. By exploring the continuities and changes between both eras (which have been treated as discrete, if not entirely disconnected) we are capable of revising certain assumptions given forth by art historical scholarship and view them as another institution of knowledge which excludes women and situates them ethnically, racially, sexually and spiritually with the lower castes and the dispossessed.

Women artists, in all our case studies, have been more or less privileged and educated, and developed a career in the Fine Arts. They all show a great interest and concern with the role of women in society, and they have portrayed and captured 
women and women's relations and work with attention and, in most cases, with a feminist or proto-feminist awareness in order to reach large audiences.

Well up until the mid-twentieth century, very few Indian women had access to an education in the Fine Arts. As a consequence, the complex gendered and class dynamics is played out in their canvases in different ways. Women's views of the world are inscribed in the material practices of those other women represented. In this specific case, the idea of the living archive and that of the "archive of feelings" is not reserved to a re-construction of the past, but is rather understood as an active source for study and reflection upon women's practices, and re-emerges with each and every particular interest, every query and new addition. No doubt, our "living archive of feelings" should keep and protect documents by projecting them and allowing them to be used and re-configured in the future, in some sort of open-ended invitation to participate.

Sunayani Devi, Amrita Sher-Gil and Nalini Malani express the multiple histories of selves and communities of which they are an integral part. Each painter in this paper, in her own way, has reconstituted the continuities of community and identity that hitherto seemed irretrievably lost.

\section{Indian Women Artists: In the Living Archive}

\section{Sunayani Devi (1875-1962)}

Devi is considered to be the first Indian "primitive"2 woman painter. She was born in Calcutta to a family of talented writers and painters with her well-known uncle Rabindranath Tagore and her two older brothers being accomplished painters. Sunayani "primitivist" art was brought to public attention around 1920-21 when the journal The Englishman commented on the bold originality of her paintings. In 1927 she was included in the exhibition of the Women's International Art Club in London.

Sunayani, as a member of the Tagore family, was very aware of the Bengal Renaissance, ${ }^{3}$ and she had an early sensitivity and inclination to the arts, whilst later

\footnotetext{
${ }^{2}$ Modernist trends in art emphasized simplicity rather than Victorian ornamentation. For example, the simplicity of village life versus the "decadence" or urban existence. As Partha Mitter (2007) and Monika Srivastava (2015), among others, have extensively discussed, Devi brought to attention an indigenous Indian modernism in the 1920 s.

${ }^{3}$ Bengal renaissance was a social, cultural, artistic, literary, educational, religious and political movement in Bengal during the period of British rule that lasted over a century, spanning the nineteenth century through the first quarter of the twentieth century (Mittra, 2001: 8-10).
} 
developing a true vocation for painting. Amina Kar, a woman sculptor from the postindependence period, explains that it "was unknown and unheard of for women to do anything, even 'Art' on a professional basis, and they remained very much in the background" (Kar, 1965: 4). The women's place was the home, the domestic sphere, and they performed the traditional functions expected of them.

As a young woman from an affluent family, Sunayani took art and music lessons as part of her education as a bourgeois lady. It was when she was in her thirties and counted upon her husband's support that she decided to take up painting. She was active for approximately fifteen years (between ages 30 to 45), and maintained a very strict painting discipline. Sunayani would paint at home, while she oversaw the daily chores of domestic workers and cared for her children. In a society that discouraged selfexpression, she worked mostly by capturing the lives of women within the household.

Feminist critics ${ }^{4}$ have focused on Sunayani's "double bind" as an artist who balanced her life as a wife and mother and as a professional painter. Although she never consciously produced "nationalist" art, her work came to be associated with anticolonialist resistance. From the 1920s onwards, critics enthusiastically welcomed Sunayani's simplicity and her allegiance to the formal values of Bengali village art. Her images of women on the street and in the inner world of the home were much valued for her expression of serenity, confidence, assertiveness and restraint. According to art critic Stella Kramrisch, her artworks have an essence of beauty expressive of two kinds of rhythm, a measured tranquillity and dignity conveying unity and truthfulness to her subject matter, and its opposite, a touch full of high spirits and movement (qtd. Mitter, 2007: 40).

Sunayani's paintings are greatly inspired by other women who shared her private inner world or immediate surroundings; they result in quaint and vibrant images which can affectively and sensuously impact audiences. Sunayani's avoidance of drawing led critics to declare that her pictures had no design but grew organically and "out of her very nature" (Kramrisch, 1925: 93). The subject matter of her art belonged to her private inner world and stemmed from reality and from the artist's imagination,

\footnotetext{
${ }^{4}$ A new generation of women art critics - Sonal Khullar, Saloni Mathur, Sabeena Gadihoke- is revisiting and rewriting the history of modern art in India focusing on the absence of women artists and thus, on the partiality and the incompleteness of a discipline which has also been used for the construction of the new Indian nation.
} 
incorporating dreams and fantasies from which she drew inspiration. In line with the increased interest in folk art, Sunayani's two major sources of inspiration came from village clay dolls —often adorning urban homes - and Khaligat paintings. ${ }^{5}$ At present, her legacy is considered to be a continuation of the simple art of the Indian village and an expression of authentic India. Thus, Sunayani's production was canonized as a prime example of "folk art" deeply rooted in the Indian soil, disregarding her emphasis on the figure of woman, women's realities and the constrictions and conventions ruling their lives. With the usual hindsight of academic art criticism, Sunayani's status should be reconsidered as a foremother of contemporary Indian women painters. Her insight into women's lives and experiences in colonial India testifies to the importance of Sunayani's archive for revisiting and analysing gender, class, caste and community in the $1920 \mathrm{~s}$.

\section{Amrita Sher-Gil (1913-1941)}

As one of the most flamboyant figures in Indian art, Amrita was the daughter of a Sikh nobleman, philosopher and Sanskrit scholar, and a Hungarian opera singer. Born in the Hungarian cultural elite, she lived her first eight years in Budapest, the following eight years in India. She was formally trained in painting in Paris, where she made an impression, both for her outstanding talent and for her scandalous social life. She became a successful professional painter, especially after she decided to return to India and to embrace her Indian heritage. There she kept her uninhibited and, at the time, outrageous lifestyle, which placed her at least a half-century ahead of her time in India. Her admired work and her controversial public persona made her attain an iconic status. This was compounded by her early death after a swift illness.

Her classic Parisian modernism, which commenced with some famous nude self-portraits, such as Torso (1931), ${ }^{6}$ evolved in India into a primitivism of pure, simple, stylized lines, at the end bearing on abstraction, centred on melancholic, sad village

\footnotetext{
${ }^{5}$ Khaligat paintings or pats belong to the nineteenth century school of Bengali painting, corresponding to the traditional art of scroll painting made in rural areas. These scrolls represented gods, mythological figures and scenes from epic poems. The Khaligats were done on cloth, and up to the 20th century they also included representations of daily life. See Jain, 1999.

${ }^{6}$ Online reproductions of all the mentioned Sher-Gil paintings are readily available on the web.
} 
subjects, projecting a tragic vision of rural India that many have interpreted as a surrogate for her divided identity.

In Partha Mitter's words, “Amrita Sher-Gil was the first professional woman artist in India whose life and career were very different from many other women artists of the twentieth century (...) Sher-Gil was nobody's muse" (2007: 51). Mitter states that Sher-Gil's most "moving" subjects were women (2007: 59) and juxtaposes an early and a late work, both non-Indian and Indian to show the painter's profound understanding of women. From Young Girls (1932) to Child Wife (1939), Sher-Gil travels the path that goes from two women sitting relaxed in front of each other, one of them with one breast bared - an interior scene of complicity and intimacy_, to the poignant Child Wife, denouncing the cruel reality of very young women given in marriage to older men, with no choice or social protection.

Sher-Gil displays a skillful training in modernist figurative techniques, similar to those of major modernist painters. In Paris, she crafted many figure studies of female models, focusing on their contours and vividly colored details, such as flowers or clothes. Her well-known canvas, the just mentioned Young Girls (1932), a double portrait of her sister Indira and a friend - placing them against a dark background and enhancing their muscular, physical presence- reflects the influence of the latest Parisian trends in the representation of the human figure and, particularly, the female body.

Sher-Gil authored many self-portraits, whilst she also used her relatives and friends as models for her work. In Europe and India, her representations of women were among the most fascinating of her oeuvre. She painted them not as external objects, as passers-by or aloof figures, but, rather, projected onto them her insight into women's identities and their reactions to the social constraints imposed upon them. Sher-Gil's bold attempts at exhibiting women's bodies and intimacies shows in a collection of female nudes, from Torso (1931), and Sleep (1933) to Professional Model (1933).

During an important touring exhibition in India, Sher-Gil met the art critic and collector Karl Khandalavala. He became a staunch supporter of her art, encouraging her to visit historic sites like Ajanta and Ellora. It is through their personal correspondence that we know of Sher-Gil's great interest in rural people and her rejection of the imitative primitivism of modernist painting. Among smaller compositions with subdued 
colours capturing the atmosphere of village life and rural types, Sher-Gil uses her expert technique and poetic vision in similar tableaux set in Hungary, such as Hungarian Village Market (1939), where an almost abstract crowd occupies the foreground and a pure white tower on top of a large rectangular building dominates the background.

By the end of her career, Sher-Gil developed a new pictorial line, in which her observations of Indian villages and their peoples were expressed through a fresh "colourism". Her discovery of distinctive colors — acid green, cobalt blue, vermillion red- present in classical old miniatures (Mughal, Pahari, Basohli), allowed her to eliminate outlines to concentrate on pure colours and masses. Sher-Gil's career came full circle embracing both the detached vision of her first encounter with India with one in which the emotional link to the daily realities of women and the rural poor through a "colourist" lens allows for a visual "archive of feelings" of images of those forgotten from official history. Mitter speaks of "elegiac images of rural women" (2007: 65) where empathy and a "monumental" vision of "authentic India" (2007: 65) persists and reaches us through the eye of a radical modernist painter.

\section{Nalini Malani (1946-)}

Born in Karachi, and raised in Bombay where she went to Art school, Malini is considered one of the more international and established contemporary Indian artists. During 1970-72 she studied in Paris with a fellowship from the French government. She is an openly feminist artist and is strongly concerned with the living conditions of women, gender violence and inequality. In her series His Life (1979-84) ${ }^{7}$ she explored relations within the family and the effects this has on the life of women.

From drawing and painting she has evolved into other media, combining video, installation, sculpture and theatre performance. Her important Medea project $(1993)^{8}$ is based on Heiner Mueller's play of the same title. In the play, Medea, the main character, loses her identity in her quest of seeking revenge for her brother's murder, and the relationship between Jason and Medea is interpreted as a metaphor of coloniser and

\footnotetext{
7 See, for instance: http://www.museumsofindia.gov.in/repository/record/ngma_mum-acc-no-0042-1296 and http://bharatbhawan.org/html/urban art014.html

${ }^{8}$ See http://www.nalinimalani.com/painting/medea.htm

and http://www.nalinimalani.com/theatre/medea.htm
} 
colonised. Hers is a politically engaged art and, at present, is concerned with issues such as migration, poverty, the oppression of women and issues of invisibility and exclusion. Malani was a refugee herself during the separation of India from Pakistan, and her work pays great attention to issues of displacement and non-belonging. Also, in her work classical literary sources combine with current popular culture.

The importance of Malani's art as a corrective to the current, widespread neoliberal agenda has proved to be crucial in raising awareness on the complexities and difficulties that dispossession, migration, ethnic conflict and violence inflict upon the disenfranchised. In Geeta Kapur's view, "Malani chooses texts that embody dispossession, that allegorize the nation's betrayal of its citizenry, that index the level of loss entailed by the populace in relation to the state. In inverse proportion to the developmental ambitions of the nation-state" (Kapur, 2008: 2).

Malani's creative versatility has gained her an international reputation, and her installations, video art and shadow plays, have become the acts of witnessing of an Indian woman and a global artist who denounces abuse, social stigmatization, exploitation and the cloak of invisibility hiding oppression and social abjection.

In her video installation Unity in Diversity, ${ }^{9}$ Malani goes back to the classical nineteenth-century oil painting by Ravi Varma's Galaxy of Musicians (c.1889) and animates it. A group of women appears clad with the distinctive Indian costumes, signifying unity in diversity. The video contrasts these images with the events of the fascist upsurge and the genocide in Gujarat in 2002 and its profound impact on Indian society at large. What starts in the video as a chant to harmony and sisterhood, finishes with bloodshed, devastation and the painful aftermath of religious intolerance and ethnic cleansing.

At present, Malani's shadow plays constitute a crucial innovation regarding genre, medium, technique, methodology and crafting. They give expression to her position as a political activist and a feminist, and seek to engage audiences in a new space created by superimpositions, rotation, light and images in motion. Drawing from the Khaligat paintings of Bengal, Malani creates a variety of forms painted on transparent cylinders, similar to magic lanterns. These superimposed images compose a

\footnotetext{
${ }^{9}$ See http://www.nalinimalani.com/video/unity.htm 
fantasy vision of a world full of creatures from an Indian and a larger transnational background.

One of her most recent shadow plays, Remembering Mad Meg, ${ }^{10}$ on display at the 2017-18 retrospective Malani exhibition at the Pompidou Centre, fuses images of girls and poor women presenting, in Mieke Bal's description,

Young girls caught in a history of violence and poverty, one with a leg blasted off by a mine, another Alice-like, skipping rope as an innocent version of reiteration, a young homeless girl or protester peeing in public space, signifying poverty but also recalling the prestigious precedent of Rembrandt (...) Goya-like torture and execution, a monster morphing into a woman, or the opposite" (2017: 15).

This installation takes its title from Pieter Brueghel the Elder, Dull Gret (Mad Meg, 1562), an alienated character who, in Malani's view, might well represent one of the last hopes for saving humanity. On other works, she draws from classical female mythic characters such as Cassandra — also from Christa Wolf's novel — to reintroduce women's histories in the male-dominated versions of the world. The aesthetic, intellectual and emotional contents (archive of feelings) of these works offers a crucial vantage point from which to reflect upon the present and future.

Clearly, Malani's most valuable archive of images of women, offers, in her own words, a way of "understanding the world from a feminist perspective [as] an essential device for a more hopeful future, if we want to achieve something like human progress [...] I think that we desperately need to replace the alpha male with matriarchal societies, if humankind wants to survive the twenty-first century" (Bal, 2017: 14).

\section{Conclusion}

Through my focusing on the representation of women by women painters, I have attempted to emphasize the erasure of borders and boundaries, together with the hybridization of styles, all of which, tellingly, illustrate specific and historicized forms of feminist resistance. Subjective experiences are contained within the specificities of each artist's spatial boundaries even while a host of local/global, village/urban aesthetics, experiences, and Weltanschauung permeate through their borders.

\footnotetext{
${ }^{10}$ See http://www.nalinimalani.com/video/remembering_mad_meg.htm
} 
Even if the category of experience as a subject of historical inquiry has often been contested (see Scott, 1991) the repeated turn to subjective experience — which each of the three painters perform - must also be understood as tactics for expressing agency within bounded spaces of pictorial language and geography. Through their strategic use of style, the painters in this paper convey bonds of relationality and emotionality with other women, across class, caste, religion, nationality and ethnicity. I suggest that, perhaps, it is this strategic use of this language of emotionality (as in Cvetkovich's archive of feelings) that facilitates the formation of genealogical links across divisions of class and caste, religion and ethnicity, communal identities and nationalities.

The feminist resistance to nationalism in India reflected in this paper points to a number of theoretical connections between pictorial language, writing, gender, and nationalism in South Asia. One could well question the fact that considering two of our three painters are from upper class privileged caste backgrounds how can they claim to represent women who do not enjoy these very positions of power? My answer would be simply that they cannot and, therefore, do not. They can, and only, reflect upon and project in their canvases a representation of their own subjective positions as women and artists, professional women and women within the public sphere. What they do bring together in their canvases, each in their own way, is the discursive relationship between the private, the personal, the domestic and the state, and as such destabilize the fixedness of each of these categories and, thus, reconfigure them over time to express their own engagement within them. Experience is thus mediated through context. In this light, neither experience, nor its subsequent interpretations remain fixed.

In the politically charged social climate of the South Asian sub-continent in the twenty-first century, and given its historical record of religious-political violence, visual representation has come to occupy a crucial space in approaching communal histories. That these painters seek to both engage in this process and resist it through their play with material elements on the canvas and their idiosyncratic style is telling of how some women have sought to transcend rigid divisions of nation and community, casting their allegiances with communities across these boundaries. They support feminist allegiances in confronting the state on the one hand, and question its validity at other times, choosing, instead, other kinds of political commitments. 
In addition to their play with pictorial language to express cross-cultural experiences, the three painters in this paper have also located themselves in the liminal spaces of society, both public and private. Their canvases reveal, incontestably, that despite the liminality of their lived, experiential realities, painting provides a strategic space they can venture out from, so as to express themselves in multiple ways.

In our living archive, Indian women find a place, the space for representation, granted by other women who are both observers and participants in the articulation of their social roles. From early on in the $20^{\text {th }}$ century, the woman painter, either as an amateur/professional artist, or an educated and expert witness of Indian reality, negotiates a space for her own agency facing the invisibility to which she was relegated to in the past.

In earlier colonial accounts the knowledge and power the male spectator presumed in viewing images of the subaltern in a world of inequality and domination, determined and constrained the space of the social. Far from those, the female gaze opens up a space for the representation of those formerly "empty signifiers" granting them existence, agency and capacities to operate in history.

\section{WORKS CITED}

ANDERSON, BENEDICT R. (1983). Imagined Communities: Reflections on the Origin and Spread of Nationalism, rev. and extended edition, London; New York: Verso. 1991.

BAL, MIEKE (2017). "Exposing Broken Promises: Nalini Malani's Multiple Exposures", In: Nalini Malani. The Rebellion of the Dead. Retrospective 19692018. Catalogue, Paris: Pompidou Centre: 15-16.

CVETKOVICH, ANN (2003). An Archive of Feelings. Trauma, Sexuality and Lesbian Public Cultures, Durham, NC: Duke University Press.

DUPLAIX, SOPHIE (2017). "Interview with Nalini Malani”, In: Nalini Malani. The Rebellion of the Dead. Retrospective 1969-2018. Catalogue, Paris: Pompidou Centre: 14.

FRASER, NANCY (1990). "Rethinking the Public Sphere: A Contribution to the Critique of Actually Existing Democracy", Social Text, Vol. 25/26: 56-80. DOI: https://doi.org/10.2307/466240. 
HOBSBAUM, ERIC J. (2012). Nations and Nationalisms since 1780. Programme, Myth, Reality, Cambridge: Cambridge University Press.

HOGAN, MÉLANIE (2012). Crashing the Archive: A Research-Creation Intervention into the Saw Video Mediatheque. Ph. D. Thesis. Montreal: Concordia University. https://spectrum.library.concordia.ca/973890/1/Hogan_PhD_F2012.pdf accessed 10 September 2018.

JAIN, JYOTINDRA (1999). Kalighat Painting: Images from a Changing World, Ahmedabad / Middletown, NJ: Mapin Publishing / Grantha Corporation.

KAPUR, GEETA (2008). "Through the Lens. Gender in Performance", Conference delivered at the School of Arts and Aesthetics, J.N.U., New Delhi, March $2008<$ https://cdn.aaa.org.hk/_source/digital_collection/.../20816.pdf $>$ accessed 10 September 2018.

KAR, AMINA AHMED (1966). "Sunayani Devi - A Primitive of the Bengal School", In: Jaya Appasamy (ed). Lalit Kala Contemporary, New Delhi: Lalit Kala Akademi: vol. 4, 4-7.

KRAMRISCH, STELLA (1925). “Sunayani Devi”, Der Cicerone, Vol. 17: 87-93.

MILL, JOHN STUART (1869). "The Subjection of Women”, In: Stefan Collini (ed). J. S. Mill: 'On Liberty' and Other Writings, Cambridge: Cambridge University Press: 117-218. 1989.

MITTER, PARTHA (2007). Triumph of Modernism: India's Artists \& the AvantGarde, 1922-1945, London: Reaktion Books.

MITTRA, SITANSU SEKHAR (2001). Bengal's Renaissance, Kolkata: Academic Publishers.

MOHANTY, CHANDRA TALPADE (2003). Feminism without Borders: Decolonizing Theory, Practicing Solidarity, Durham, NC: Duke University Press.

NORA, PIERRE (1989). "Between Memory and History: Les Lieux de Mémoire", Representations, Vol. 26, Special Issue: Memory and Counter-Memory, Spring: 7-24. DOI: https://doi.org/10.2307/2928520.

SARKAR, TANIKA (2010). Hindu Wife, Hindu Nation. Community, Religion and Cultural Nationalism, Bloomington, IN: Indiana University Press.

SCOTT, JOAN W. (1991). "The Evidence of Experience”, Critical Inquiry, Vol. 17, No4: 773-797.

SPIVAK, GAYATRI CHAKRAVORTY (1983). "Can the Subaltern Speak?”, In: Cary Nelson \&Laurence Grossberg (eds). Marxism and the Interpretation of Culture, Urbana, IL: University of Illinois Press: 271-313. 1988. 
SRIVASTAVA, MONIKA (2015). Renaissance in Indian Art, 1900-1947. PhD diss. Lucknow: University of Lucknow.

WILLIAMS, RAYMOND (1958). "Culture is Ordinary", In: Resources of Hope: Culture, Democracy and Socialism, London: Verso: 3-18. 1989.

MiRANDA IMPERIAL is a University of Cambridge (Human, Social, and Political Sciences) graduate, currently studying an MSc in Political Communication at the London School of Economics. Her work under the direction of Prof. Christine Garlough (U. Wisconsin-Madison) on the South Asian Feminist Activist Archive is in press (Oxford U. Press). Her interests center at the intersection of Social and Political Theory and Gender Studies. 